Pirineos, 163: 37 a 50, JACA; 2007. ISSN 0373-2568

\title{
DISAPPEARANCE OF THE GLACIER ON MAMA COTACACHI: ETHNOECOLOGICAL RESEARCH AND CLIMATE CHANGE IN THE ECUADORIAN ANDES
}

\author{
R. RHOADES
}

Department of Anthropology, University of Georgia, 264 Baldwing Hall, Athens, GA 30602. USA. c.e.: rrhoades@uga.edu

ABSTRACT.- A first documented case study of a disappearing glacier in the snow capped volcano Cotacahi in Ecuador is presented with the studies belonging to the social sciences in relation to climate change and its impact on the population of the Equatorial Andes. With the use of multiple source methodology, including ethnographic analyzes, visual representations, repetitive photography, critical mapping by the local communities, longitudinal surveys, even archival research, as well as interviews to social actors and utilization of spatial data in a geographical information system (GIS). It is concluded that the documented disappearance of the glacier on the Cotacahi serves as an urgent call for action to the important dearth of social research related to global change from the ethnoecological perspective, with a cultural, local approach.

Key words: Climate change, Northern Andes, Indigenous People, Methodology, Cotacachi, Ecuador.

RESUMEN.- Se presenta el primer estudio documentado de la desaparición del glaciar del nevado Cotacachi en el Ecuador, con los estudios que corresponden a las ciencias sociales en relación con el cambio climático y su impacto en la población de los Andes ecuatoriales. Mediante el uso de una metodología que incluye análisis etnográficos, representaciones visuales, fotografía repetitiva, mapeo crítico por parte de las comunidades locales, encuestas longitudinales e incluso investigación de archivos, así como también entrevistas a actores sociales, y utilización de los datos espaciales en un sistema de información geográfica (SIG). Se concluye que la desaparición documentada del glaciar del Cotacachi sirve como una llamada de atención urgente a la importante falta de investigaciones sociales relacionadas con el cambio global desde el punto de vista etnoecológico, con un enfoque cultural local. 
Palabras clave: Cambio climático, Andes del Norte, pueblos indígenas, metodología, Cotacachi, Ecuador.

\section{Introduction: Mountains as Earth's Bellwether}

Unprecedented social and environmental impacts from rapidly melting ice in the Andes, Himalaya, and Alps tragically provide an early glimpse of what might be in store in the near future for Earth's densely populated lowlands. In this regard, mountain environments offer a unique laboratory for understanding the impacts of climate change and variability on human societies wherever they are located. Alpine regions are characterized by a sharp vertical juxtaposition of vegetation zones controlled by altitudinal, edaphic and climatic factors. The narrow biotic ecozones on a tropical mountainside roughly duplicates within a few hundred meters of elevation the world's major biomes stretching from tropical forests to permanent snow. Long-term adaptations to the realities of mountain verticality have taken many forms but historically, under regimes of agriculture and pastoralism, a typical exploitative pattern involves specialized utilization of the tightly compressed zones in a dynamic, integrated system. Settlements, cropping patterns, irrigation, animal utilization, forests and terracing typically reflect the exigencies of the natural vertical layering of the mountainside. At the same time, minor changes in climate and the resultant shifts in zones, will require new adjustments and adaptations in human exploitative patterns. In many mountain regions, different social and ethnic groups occupy different zones and ecological niches along a mountainside. Ancient systems of trade, barter, water sharing, and social exchanges have allowed groups to survive even when their own land is insufficient for a whole society's needs. What happens, then, when climate changes so dramatically that these time-tested systems of relationships between people and the land, and between human groups are no longer relevant?

My career as an Anthropologist has focused on analysis of change between traditional cultural dynamics of rural households and sustainable development in mountainous regions around the world. Typical of most mountain ethnographers, I spent many years living in remote villages where I delineated the characteristics of indigenous knowledge, social organization, and technology. While mountain villagers are frequently portrayed as backward by outside development "experts", my long-term research demonstrated that in fact their decision-making is often adaptive within local contexts. For instance, my comparative work in the Himalaya, Andes, and Alps documented that mountain farmers have created finely-tuned and 
diversified coping strategies for utilizing marginal terrain. I contrasted these adaptations to Western flatland conceptions of land use and demonstrated why an external lowland mentality is often the basis of failed projects. Through these and other locally anchored studies, I have contributed to a paradigm shift in development thinking which today respects indigenous knowledge and encourages community-based participation. What happens, however, when completely unknown environmental events confront a local people's longstanding knowledge?

\section{Cotacachi: A Vanished Mountain Glacier}

During my recent research in the Ecuadorian Andes (1998-2005), a stunning and unpredicted event brought me to rethink adaptive capacity of traditional knowledge in the face of global climate change (RHOADES, 2006). This re-evaluation of my perspective set in motion a new line of personal scientific inquiry into the relationship between local decision-making and what climatologists now call "climate variability". The dramatic event was the rapid melting and complete disappearance of the glacier on the 4939 meter peak of Mount Cotacachi below which we conducted our research. Known locally as Mama Cotacachi, the mountain and its ice are sacred to 18,000 Indians living in 41 nearby communities. The glacier which dates back 20,000 years to the Great Ice Age provides water and nourishes fields, livestock, and homes and is central to their native cosmology. Rather suddenly, however, the glacier lake above the communities started dropping a meter in depth per year while rivers and springs began to dry up across the landscape. Social conflicts between Indian communities, landlords, and the government began to boil over due to competition for water resources. The anthropological literature on indigenous knowledge has largely drawn on local people's long-term direct experiences with past and recurring patterns in their environment. The demise, however, of the Cotacachi glacier and subsequent environmental changes in the landscape were entirely new phenomena for Cotacacheños. They have no collective memory of their homeland without the glacier and no cultural framework for understanding why the ice disappeared or for coping with the consequences.

Since the end of the Little Ice Age between the $16^{\text {th }}$ and the $19^{\text {th }}$ centuries, glaciers have been retreating in the Andean tropical mountains. Across the Andes, glaciologists predict that $80 \%$ of all glaciers will disappear within 1520 years (TGS, 2001). Bolivia's 1,830 glaciers, which accounts for around 20\% of the world's tropical glacier area, will largely disappear within 10 to 20 years (JORDAN, 1991). During the last 50 years, glacier shrinkage in the 
Ecuadorian Andes has dramatically increased (GARCIA \& FRANCOU, 2002). Individual mountain peaks in Ecuador show different stages of glacier melting. On one hand, Chimborazo, Cayambe, Antizana, and Cotopaxi glaciers-mainly higher mountains along the eastern cordillera- are in an ongoing melting process. On the other hand, Cotacachi, Corazón and Sincholagua located on the western cordillera are good examples of mountains that have completely lost their glaciers within the past 5 to 10 years.

Cotacachi presents an interesting case for understanding local people's early perceptions and responses to the unanticipated disappearance of an important cultural symbol and livelihood resource. As our team began to study climate change in Cotacachi, we discovered that the Andean and world literature on how mountain glacier retreat impacts society was virtually nonexistent (RHOADES et al., 2006; RHOADES et al., 2008). As a result, we saw an urgent need for the scientific community to begin the process of documentation and monitoring the interaction between climate change and human communities. Considerable scientific information is available about the physical loss of glaciers, thanks to the work of glaciologists, but little is known about how local people adapt or are impacted. While climate change/variability was identified by indigenous people in various surveys we conducted in Cotacachi as the primary factor in the change of agricultural practices and availability of water, our research revealed a great deal of ambivalence and uncertainty about what the loss of the glacier ultimately means in their lives.

\section{A Multi-source Methodology}

Given that no available methodology was available to understand the societal impact of mountain glacier retreat, we opted for a multiple source approach to accumulate a broad range of information. The sources included historical archives, historic photographs, landscape paintings, recent photographs of our research team, meteorological data, and participatory workshops and interviews with local people using visual aids (3D participatory models of the landscapes, aerial photographs, and panoramic photos). We were interested to see if there was any correspondence between the scientific and historical information and local people's own observations and knowledge. Details of our research have been published elsewhere, but a summary of the kinds of available information demonstrates that even in remote mountains the story of glacier demise can be historically reconstructed (see RHOADES et al., 2006; RHOADES et al., 2008). 


\subsection{Historical Documents}

Chroniclers, mountaineers, explorers, and tourists provide written documentation useful for reconstructing Ecuador's Andean glaciers over the past two centuries. These historical documents were located in libraries, museums, and archives in Cotacachi and Quito. Description of Cotacachi volcano's glaciers date from the early era of the Spanish colonization and from the accounts of travelers and scientists like Humboldt, Wagner, Orton, Dressel, Whymper and Wolf (see table 1). While these written sources provide invaluable information on location, extent and conditions of specific glaciers from the point of view of foreigners, they provide almost no information on the view of local people (see CRUIKSHANK, 2005).

Table 1. Selected accounts of Cotacachi glacier: $19^{\text {th }}$ Century.

\begin{tabular}{|l|l|}
\hline $\begin{array}{l}\text { Alexander von Humboldt (1853: } \\
\text { 21) in 1802 }\end{array}$ & $\begin{array}{l}\text { "The Pichincha Mountain is located in the same direction } \\
\text { and axis than the snow capped mountains Illiniza, } \\
\text { Corazón, and Cotacachi". }\end{array}$ \\
\hline $\begin{array}{l}\text { M. Wagner (1870:627-628) between } \\
\text { 1858-1859 "The low perpetual snow frontier for Cotacachi in May is } \\
14,814 \text { feet (4,515 masl) above sea level". }\end{array}$ \\
\hline $\begin{array}{l}\text { J. Orton-an American explorer in } \\
\text { 1867 }\end{array}$ & $\begin{array}{l}\text { "Twenty-two summits are covered with perpetual } \\
\text { snow...The snow limit at the equator is 15,800 feet (4815 } \\
\text { masl). Cotacachi is always snow-clad". }\end{array}$ \\
\hline $\begin{array}{l}\text { Dressell in 1877 (quoted in } \\
\text { Hastenrath, 1981:99) }\end{array}$ & $\begin{array}{l}\text { Cotacachi summit is "covered with perpetual and } \\
\text { compacted snow". }\end{array}$ \\
\hline Edward Whymper in 1880 & $\begin{array}{l}\text { "Permanent snow, in large beds, as low as 14,500 feet } \\
\text { (4419 masl)...it is not likely that a crater lies buried } \\
\text { beneath the glacier which at present occupies the } \\
\text { depression between its peaks". }\end{array}$ \\
\hline T. Wolf in 1892 & $\begin{array}{l}\text { "The Cotacachi is the only snow capped mountain that } \\
\text { is found between the Guayllabamba valley and the Mira } \\
\text { River. It has a big glacier on the east side". }\end{array}$ \\
\hline
\end{tabular}

\subsection{Paintings and Photographs}

Another source for understanding the decline of Andean glaciers are landscape paintings and photographs which have been made over the centuries (Figure 1). Many of the same chroniclers mentioned created sketches and paintings of the peaks they encountered. For Cotacachi, Edward Whymper and T. Wolf independently produced in 1892 the first known 
artwork of the Cotacachi mountain. The famed Ecuadorian artist, Rafael Troya, provided another painting in 1913.

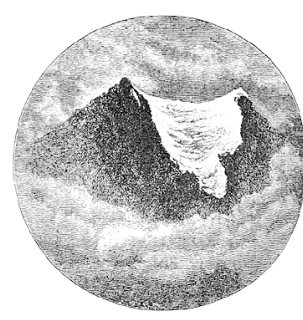

Cotacachi. East side. Edward Whymper (1892)

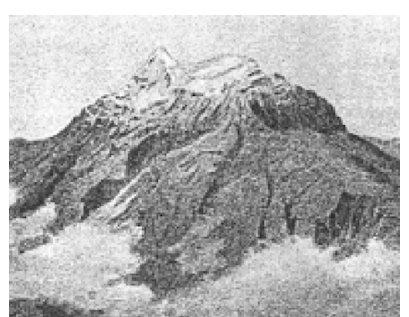

Cotacachi. Northeast side. T. Wolf (1892)

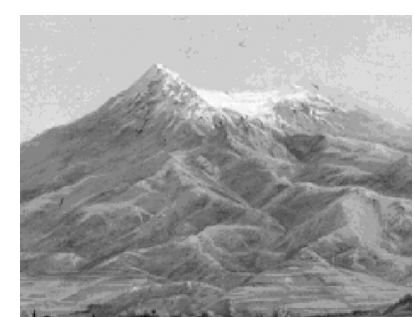

Cotacachi. East face. Rafael Troya (1913)

Figure 1 . Sketchings and paintings of Cotacachi, late $19^{\text {th }}$, early $20^{\text {th }}$ centuries.

Historical photographs are also available to create a time-series of changes in the glacier area. In the village square of Cotacachi we purchased an 1890 photograph of the Cotacacachi volcano (Figure 2a). Also, our own project (SANREM) took numerous photographs between 1997 and 2006, years corresponding to the disappearance of the glacier (Figure 2b). Together, these photographs provide an excellent visual timeline of the demise of the Cotacachi glacier.

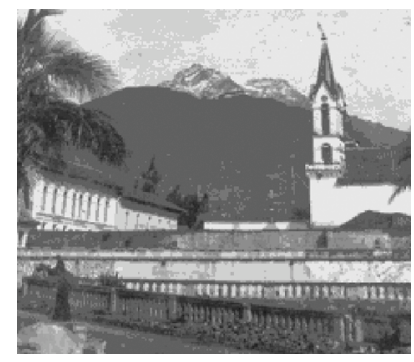

2a. Cotacachi. East face (Photo: Anonymous, around 1890)

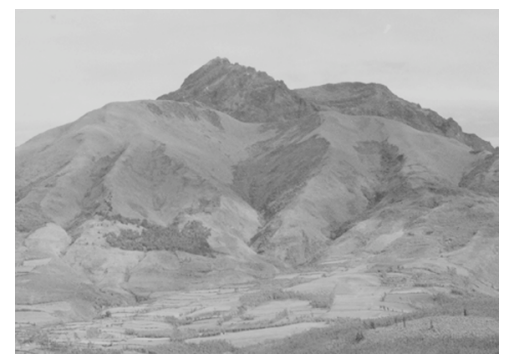

2b. Cotacachi. East face (Photo: Rhoades 2002)

Figure 2. Photographs documenting demise of Cotacachi glacier. 
Aerial photos from Ecuador's Military Geographical Institute (IGM) were also collected to observe glacier change in the last 40 years. Our time-series analysis of the aerial photos from 1963, 1978, 1993 and 2000 showed a rapid decline and ultimate demise of the glaciated area (ZAPATA et al., 2006). The Aerial photos and a 3D geo-referenced model of the mountain area were especially useful as visual aids in participatory workshops with local people (Figure 3).

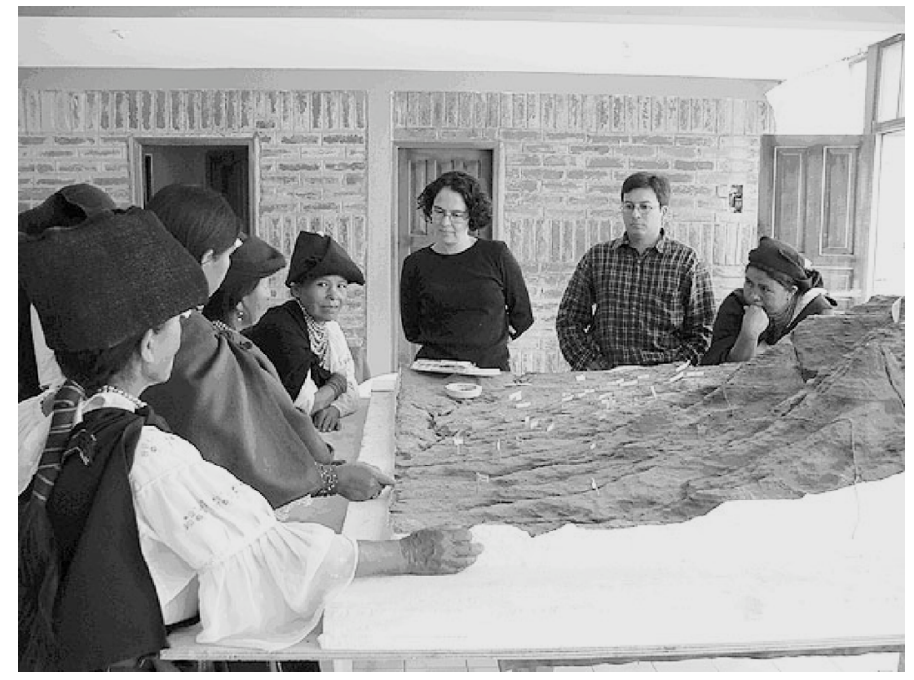

Figure 3. Participatory discussion about water and climate in Cotacachi, Ecuador, using a 3-D model (Photo by Aragundy 2006).

\subsection{Meteorological Data}

Rarely do mountainous regions of developing countries possess meteorological data sufficient for climate change analysis. However, clear evidence of climate change in Ecuador-including tendencies of air temperature increase and precipitation decrease over the last century-are found in the national meteorological record (CACERES, 2004). Most of the national weather stations are quite dispersed and only permit regional level generalizations. Ecuador's Institute of Meteorology and Hydrology (INHAMI) carried out a precipitation and temperature variation analysis to study climate change over a 40-year period in the northern part of Ecuador where Cotacachi is located. These results showed an increasing tendency in 
the mean, maximum and minimum annual temperatures, and decreasing precipitation levels (CACERES, 2004). We supplemented this information with records of precipitation and temperature from two haciendas near Cotacachi. The combined meteorological datasets correspond to local people's own perceptions that the area is becoming warmer, rain patterns are unpredictable compared to the past, and precipitation has decreased over the past few decades.

\subsection{Participatory Workshops and Interview with Local People}

Using a 3-D participatory physical model, we convened 20 farmers from different Cotacachi communities (Figure 3). The replica of Cotacachi mountain (scale: 1-35,000) facilitated interaction in identifying key features of the landscape (snow zone, springs, rivers, roads) and changes which had occurred. During the workshop, people were very adamant in declaring that the climate was changing but there was reluctance in admitting or understanding that the glacier had disappeared. The permanent snows of Cotacachi are etched in the minds and memories of the people of Cotacachi. In their local artwork, they always paint the mountain with a large zone of permanent snow despite its recent disappearance. Not too many years ago, ice from the glacier was a valuable local good. Its was harvested by hieleros (ice porters) who climbed the mountain, harvested glacier ice and then transported it to Ibarra (the largest nearby city) for food and medicine preservation. The glacial ice was also thought to have its own healing powers and was collected for curing.

Without a scientific explanation and little understanding of global climate change forces, the indigenous people of Cotacachi offer explanations that fit with their own cosmologies. Mama Cotacachi, the local name of the scared mountain, is a feminine power requiring reverence and special dedication. The loss of the glacier and decline of water resources is thought by some to be God's punishment for unacceptable actions by the communities (e.g., deforestation, grazing, infighting and moral decline). Young people, on the other hand, allege that the changes are due to global warming caused by industrial nations like the United States. They glean this information from the press and local NGOs. In nearly all communities, people have prayed for rain through water ceremonies, or food offerings that are buried to give back to the land the products that people receive from "Mother Earth" (Pachamama).

The most salient perceived change is in the seasonal rain pattern which is directly related to every day concerns. Although most Cotacacheño households engage in off-farm employment, their livelihoods still depend on 
agriculture and natural resource use. In fact, almost any discussion with a local farmer begins with the observation that there is less and less rain for farming. Increasingly scarce and highly irregular rainfall causes confusion over field preparation and planting times. Strong winds affecting agriculture and declining water availability are also frequent observations of local people. Older villagers remember when the rivers had stronger flows and the springs produced abundant water. The rapid melting of the glacier over the past century led initially to an abundance of water for communities. The Pichaví, Yanayacu, Pichanviche and Alambi rivers, in and several creeks and springs, were the main water source for people at the beginning of the $20^{\text {th }}$ century. Today, locals say these rivers are more like canals than rivers. Springs are drying up and some large communities now depend on very small sources.

\section{Climate change, water, and conflict}

Until land reform in the 1960s, most indigenous communities were subservient to haciendas, large extensions of land owned by single families. As in a feudal system, indigenous families worked for the hacienda as near serfs in exchange for access to a small parcel of hacienda land, water and firewood. To support hacienda agriculture, large irrigation channels were built in the area over the centuries, such as 'La Marqueza' channel and the old Imantag system. After land reform in 1964 and 1973, haciendas were partially subdivided and redistributed to indigenous people who had previously worked on the hacienda. In 1963, Cotacachi, haciendas covered 5,523 ha or about $25 \%$ of the area, whereas in the year 2000 they covered 3,048 ha, or 13,9\% (ZAPATA et al., 2006). At the time of land reform, however, there was no corresponding water reform. The larger concessions to water remained under the control of the haciendas, despite their reduction in size.

With the creation of new communities and farms after land reform, the indigenous leadership began to pressure government authorities for more equitable access to water. Moreover, the local population increased dramatically over the past 40 years, placing even more pressure on the water supply. According to the National Institute for Statistics and Census (INEC, 2001), current human population in the area is 25,223 inhabitants with a population density of 115 inhabitants $/ \mathrm{km}^{2}$. This is double the population and density of 1962. During the 1990's, farmer communities, with support from UNORCAC (Union of Peasant and Indigenous Organizations of Cotacachi) and national and international donor agencies, built several new water systems, such as Cambugan, Chumaví and the new Imantag system. 
Currently, despite the contribution of the new systems, the water situation in the region is not encouraging. Almost all of the 41 indigenous communities, towns and haciendas have drinking water systems that function poorly. Lack of maintenance, poorly designed systems, and decreased water availability are some of the reasons for this inefficient service. Agriculture remains the main economic activity for Cotacachi but only few communities have access to irrigation. Local people have been trying to expand irrigation systems to a wider area, however there are no unused water sources close to the communities.

Throughout the region there is growing evidence of conflict over water sources (Figure 4). In the 'La Marqueza' system, water flow has dramatically decreased leading to conflicts among users. Legal issues over concessions are arising between hacienda owners, indigenous communities, and the central government. Local authorities predict that conflict will increase dramatically in the coming years if nothing is done to reverse the situation (SANREM, 2004). During July 2005 open conflict erupted in the area when indigenous groups around Imbabura Province of Cotacachi blockaded the Pan American highway and demanded greater access to water (Diario HOY, 2005).

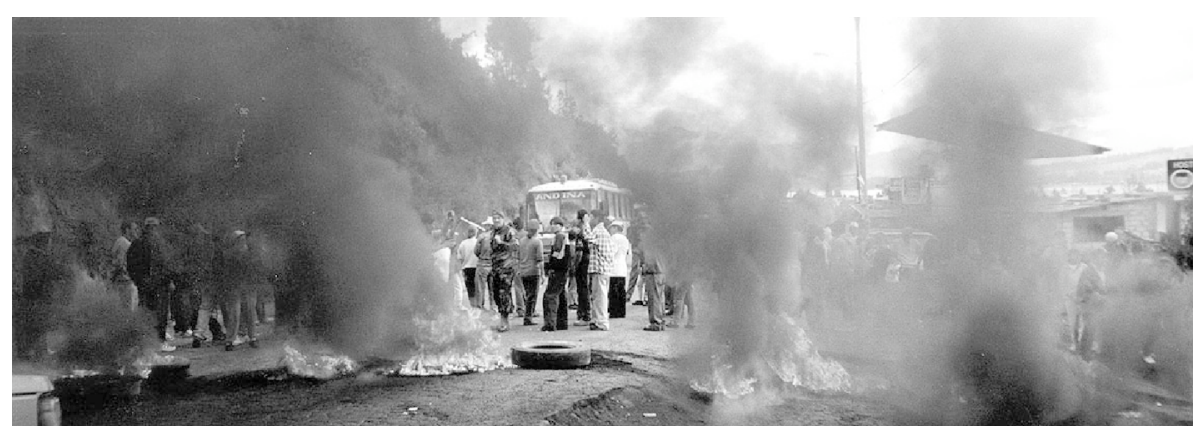

Figure 4. Indigenous protest over water rights in Northern Ecuador.

\section{Conclusion}

The findings on a mountain people's immediate and local responses to the demise of a tropical mountain glacier which has always been a part of their history and culture has been documented. While doing research in Cotacachi it became clear that global warming was reshaping the landscape of Cotacachi and the lives of the people. As we struggled to understand the phenomenon and how locals were reacting, we encountered methodological 
and operational research difficulties. There was little in the social science literature in particular that gave us guidance or comparative information to understand the Cotacachi case.

Most of the information we gathered from any single source was sparse but by using them as pieces of a larger puzzle, we were able to construct a wider vision of Cotacachi's glacier demise and its social consequences. As we have seen from the historical, visual and climatological information, the local perception of climate change in Cotacachi cannot be written off as nostalgia or inadequate recall. Local people are aware and are able to articulate climate change and its impacts on their lives. By combining different forms of evidence we have been able to link bio physical evidence of glacier retreat with human perception. While social science researchers in tropical mountains may find the lack of systematic information on glacier retreat disappointing, we have demonstrated that by utilizing a multiple source methodology a great deal can be understood in a short amount of time. There is a need to further refine the methodology and seek more profound ways to measure both scientific indicators of change and how local people understand the same changes.

Our assumption is that by understanding local people's awareness of weather and climatic change, we can also understand better their decisionmaking and local adaptations to global change. One question centers on the relation between present indigenous knowledge of the environment and global climate change as manifested locally. Logically, farmers' local knowledge forms the basis of decision making and it should be incorporated into any strategy meant to mitigate the impact of climate change (VEDWAN \& RHOADES, 2001). However, it should be fully realized that the demise of the Cotacachi glacier and consequences for water availability are entirely new to Cotacacheños. The glacier was always there in their collective memories and Mama Cotacachi always supplied abundant water. Local people have no previous experience with something as dramatic in their lives as the disappearance of the glacier, which has always dominated the physical and cultural landscape of their homeland. Although contrary to anthropological dogma on indigenous knowledge, it is probable that local knowledge systems of Cotacachi are inadequate in the face of external global change and this possibility underscores the critical need for cross-fertilization between local understanding and scientific analysis.

Mountains are excellent laboratories for the study of climate variability and societal response. The compactness of mountains and the fineness of human adaptation will mean that change and response will come quicker to the mountains than any other ecosystem. However, social scientists have yet 
to capitalize on this potential through in-depth case studies and comparative research. Comparative research should first take place within regions-like the Ecuadorian Andes-and subsequently with other world alpine regions. For example, our team also conducted preliminary research in the Cayambe mountain region located approximately 50 kilometers southeast from Cotacachi. We discovered both similarities with the Cotacachi case but also dramatic differences. Cayambe, which is 800 meters higher than Cotacachi and located on the Eastern Cordillera, still has a large glacier. Over the past two decades, the region has experienced a tremendous boom in the floriculture industry which provides employment to mestizo and indigenous communities which, in turn, depend less on farming. While Cayambe may be sitting on a melting economic bomb, just as in the case of Cotacachi, the awareness or the level of concern about climate change and the loss of the glacier is at a much lower level compared to Cotacachi. Whether Cotacachi or Cayambe, one thing is certain: not only will the loss of the glacier and the water supply dramatically affect the productive economy-whether smallscale agriculture or the floriculture industry-but it will dramatically alter Andean landscapes. This has both spiritual and economic ramifications. Mama Cotacachi is sacred. She is a powerful force in the community but people sense she is dying. The shamans of Cotacachi feel their own powers diminishing and this too is symbolic of a people in social decay. They believe the fate of the mountain will be the fate of the people. In addition, both Cayambe and Cotacachi are starting to bank on their mountain vistas to attract international tourism as a possible path out of poverty. The two mountains contain some of the most stunning landscapes in the Andes. With the Cayambe-Coca National Park and the Cotacachi-Cayapas Ecological Reserve, this northern Ecuadorian area is attracting larger and larger numbers of tourists. Indigenous people have responded to these possibilities by establishing tourist agencies and building guest houses in the villages. Adventure tourists come to live with families and to trek to the highlands. But one can only ask: if the glaciers disappear and the mountains turn black, will the attraction be the same?

We urgently need to understand what is happening on the ground in those communities which have historically depended on the glacier. This calls forth a vigorous social science, linked with the natural sciences that are attempting to address the issue of global climate change. Only with a strong interdisciplinary approach involving the participation of people directly affected can we hope to achieve short-run or long-term solutions to what portends to become major disruptions of ancient cultures deeply rooted in glacier-fed mountain landscapes. 


\section{References}

CÁCERES, L., MEJIA., R. \& ONTANEDA, G. (2001). Evidencias del cambio climático en Ecuador. http://www.unesco.org.uy/phi/libros/enso/ caceres.html. Quito: INHAMI.

CRUIKSHANK, J. (2005). Do Glaciers Listen? Local Knowledge, Colonial Encounters, and Social Imagination. Vancouver, Canada: University of British Colombia Press.

DIARIO HOY. (2005). Bloqueo en la Panamericana por bloqueo de indigenas. July 5.

GARCÍA M. \& FRANCOU, B. (2002). El corazón de los Andes. Ediciones Libri Mundi. Quito-Ecuador.

HASTENRATH, S. (1981). The glaciation of the Ecuadorian Andes. A.A. Balkema Rótterdam.

HILLBRANT, C. (1989). Estudio geovulcanológico del complejo vulcánico Cuicocha-Cotacachi y sus aplicaciones. Provincia de Imbabura. Tesis previa a la obtención del titulo de Magíster en Geología. Quito.

HUMBOLDT, A. (1853). Kleinere Schriften. Vol. 1. Stuttgart: Cotta.

INSTITUTO NACIONAL DE ESTADÍSTICA Y CENSOS. (2001). VI censo de Población y $V$ de Vivienda. Quito. INEC.

JORDAN, E. (1991). Die Gletscher der Bolivianischen Anden. Stuttgart: Franz Steiner.

CIRCULO DE LECTORES, (1978). Maravilloso Ecuador. Impreso en la industria gráfica Provenza, España.

MAYORGA O. (2004). Informe sobre el sistema de agua entubada Chumaví. Quito: Pontificia Universidad Católica del Ecuador y Proyecto SANREM-Andes.

ORTON, J. (1870). The Andes and the Amazon; or Across the Continent of South America. New York: Harper.

RHOADES, R. (2006). Development with Identity: Community, Culture, and Sustainability in the Andes. Oxon, U.K. and Cambridge, Mass.: CAB International Publishing.

RHOADES, R., ZAPATA, X. \& ARAGUNDY, J. (2006). Climate Change in Cotacachi. In R. RHOADES (Ed). Development with Identity: Community, Culture and Sustainability in the Andes. Oxon, U.K and Cambridge, Mass.: $\mathrm{CAB}$ International Publishing.

RHOADES, R., ZAPATA, X., \& ARAGUNDY, J. (2008). Mama Cotacachi: History, Local Perceptions, and Social Impacts of Climate Change and Glacier Retreat in the Ecuadorian Andes. In Benjamin ORLOVE (Ed). Darkening Peaks. Berkeley: University of California Press.

SANREM (Sustainable Agriculture and Natural Resource Management). (2004). Workshop on Water. Hotel El Meson. Cotacachi, Ecuador. Jan. 20. 
THE GEOLOGICAL SOCIETY. (2001). Geology news: Small Andean Glaciers will have vanished in 15 years. http:/ / www.geolsoc.org.uk

VEDWAN, N. \& RHOADES, R. (2001). Climate Change in the Western Himalayas of India: A study of local perceptions and response. Climate Research 19: 109-117.

WAGNER, M. (1870). Naturwissenschafliche Reisen im Tropischen Amerika. Stuttgart: Cotta.

WHYMPER, E. (1994). Viajes a través de los Majestuosos Andes del Ecuador. Ediciones Abya-yala. Colección Tierra Incógnita 4. Quito.

WOLF, T. (1892). Geología y Geografía del Ecuador. Leipzig: Brockhaus

ZAPATA, X., RHOADES, R., SEGOVIA C. \& ZEHETNER, F. (2006). Four Decades of Land Use Change in the Cotacachi Andes: 1963-2000. In R. RHOADES (Ed.). Development With Identity: Community, Culture, and Sustainability in the Andes. Cambridge, MA and Wallingford, UK: CABI Publishing. pp. 46-74. 